\title{
INDEXES
}

Numbers in Roman type provide references for persons and places mentioned in the documents, including the Leake copies (Appendix I) and the summaries in the royal confirmation (Royal Conf.) in I3I6 (Appendix II). Italics are used when personal or place-names are otherwise mentioned. Persons and places in the Introduction are noted with the relevant page number (e.g. 'Intro. 6').

All persons are listed by first name. Some entries may conceal separate identities; likewise some entries may refer to the same person or place. 'De' (as in 'Nigel de Stokes', for example) has always been replaced in the Indexes by 'of'. Place-names are given in their modern form wherever possible.

$\mathrm{D}=$ historic county of Derbyshire; $\mathrm{L}=$ Leicestershire; $\mathrm{N}=$ Nottinghamshire; $\mathrm{SH}=$ ancient parish of Sheffield; $\mathrm{SY}=$ South Yorkshire; fd. $=$ found.

\section{INDEX OF PERSONS}

\section{i) Persons other than witnesses}

Adam Barry of Nottingham 22I

Adam of Birchwood, D 22, $3^{8}$

Adam le Blunt Intro. 29

Adam the carter of Brincliffe, $\mathrm{SH}$ I26-I28, I39-I4I, I49

Adam the cook of Sheffield I29, I50-I5I

Adam of Glapwell, D 213

Adam of Greenhill, D 52, 55

Adam Hutun son of Eudes (Odo) Leneire 88

Adam Lawnder Intro. 19

Adam of Milum (Cumberland?) 66

Adam of Saint Mary (of Rawmarsh, SY) Intro. 6, ${ }_{137}-138$
Adam son of John of the Cliffe, D 21, 38, 49

Adam son of Ralph of Reresby, L and of Margery 183

Adam son of Richard the ditcher 155

Agnes of Birchwood, D 68

Agnes daughter of Robert of England I5I

Agnes of Orby (Lincs) 4 . 3

Agnes wife of William of Dronfield, D I59

Alan 4, 38

Alan son of Gunnild of Chesterfield, D Intro. $11, \mathrm{I} 97$

Alan son of Richard 2II

Albert of Bradway, D 38

Alexander 5, $3^{8}$ 
Alexander son of Alexander of Birchwood, D 89

Alice of Alfreton Intro. 7

Alice daughter of William son of Robert of Alfreton, D Intro. Io, 64, 76

Alice Loole 43

Alice wife of Walter of Buildwas (Shrops) 220

Alice wife of William of Briges I92-I94

Amice (Amitia), wife of Nigel of Stokes Intro. 30

Andrew of Hooton, SY Io6

Avice 2I2

Beatrice wife of Robert Hauselin (of Little Sheffield, SH) I29

Boniface IX, pope I3

Brun Gerard I34

Cecily aunt of Hugh of Scholes, SY 97

Cecily Leche 219 n. I

Cecily of Tamworth (Staffs) 219 n. I

Cecily wife of Ralph of Ecclesall, SH in I

Cecily wife of Thomas of Beeley, D Leake 6

Christopher Blackwall Intro. 15

Christopher Haslam Intro. 20

Clebern 3

Daniel the butler, brother of Walter I04

Edmund Deincourt Intro. IO

Edward Pegge Intro. I4, Intro. 23

Edward of Scholes, SY Ioo

Edwin 199

Ellen wife of Adam the cook of Sheffield I29

Ellis the carpenter Intro. $I I, 98$

Ellis the steward I25

Ellis of Troway, D 8, 38

Emma at the new mill, SH 35

Emma wife of Richard the redsmith 69

Emma wife of William of Lovetot Intro. 6, I29 n. 2

Francis Leake, knight, of Sutton, D Intro. I6, Intro. 17 , Intro. 23

Francis Talbot, $5^{\text {th }}$ earl of Shrewsbury Intro. 15, Intro. 23

Gamel Intro. $1 I, 3$

Gamel of Ecclesall, SH II7

Gamel son of Solon I35
Geoffrey (Galfrid) Leake 7

Geoffrey Barre, knight, of Teversal, N 66, 203

Geoffrey Blythe, bishop of Conventry and Lichfield Intro. 12, Intro. 29

Geoffrey of Stanley, N 222, 225-226, Royal Conf. 45

George son of Sir Thomas Chaworth Intro. $7 n$

Gerard Intro. II, 3, I36

Gerard of Furnival, knight Intro. 6, Intro. 8, Intro. I5, Royal Conf. 37-40, Royal Conf. 42

Gerard of Greenhill, D 6, 38

Gertrude Strelley Intro. 23

Gervase Intro. II, 3

Gervase son of Richard the good smith 198

Gilbert, abbot of Beauchief Intro. 28, $217 n$. 3

Gilbert of Bradway, D 35

Gilbert of Hasland, D I92-I93

Gilbert of Perlethorpe, N 95-96

Gilbert the smith 20I

Godric of Darley, D I69

Gunnild of Chesterfield, D I97

Gunnild of Sheffield I 48

Hacon Intro. $I I, 3$

Henry the bercher 2I

Henry, clerk of Chesterfield, D i99

Henry Coke, chaplain 219 n. I

Henry of Egmanton, N I85

Henry Fraunc Io9

Henry of Herries $26 n$. 4

Henry the mason of Ecclesall, SH Intro. 20

Henry of Mousters of Ashover, D I84

Henry of Scholes, SY 94

Henry son of Gunnild of Sheffield I 48

Henry son of Laurence ioI

Henry son of Thomas of Bradwell, D I05

Henry son of William the tanner I34

Henry Stafforth, knight Intro. $2 I$

Herbert of Orby (Lincs) $4 n .3$

Hugh Intro. $I I, 4,38$

Hugh II, abbot of Prémontré Intro. 26, I, 2

Hugh of Avallon (St Hugh), bishop of Lincoln 59 n. I

Hugh of the Barkhouse Intro. 19

Hugh Bauzan Io9

Hugh Bridde IOI

Hugh the cook $137^{-1} 3^{8}$

Hugh Draper of Chesterfield, D 219 n. I

Hugh of Duffield, D i78 
Hugh of Glapwell, D 206, 209-2IO, 2I2, 2 I4 Hugh Hauselin of Little Sheffield, SH i 8 , I26-I27, I30-I33, I49, I56, I58

Hugh, knight and rector of Handsworth, SY Intro. $2 I$

Hugh of Linacre, D I 8 nn. I and 2

Hugh of Little Norton, D 33, 38, 40

Hugh of Scholes, SY 98, I03

Hugh the smith ${ }_{13} 6$

Hugh son of Adam at the spring in Greenhill, D Intro. IO, 55

Hugh son of Albert of Bradway, D 6, 38

Hugh son of John of Duffield, D I77-I78

Hugh son of Ralph of Scholes, SY 105

Hugh son of Robert of Scholes, SY 93-94, 97

Hugh son of Robert of Walton, D I9o

Hugh son of Sweyn 204

Hugh son of William 94

Hugh Wake (of Chesterfield) I6o, I95

Hugh of Wells, bishop of Lincoln 59 n. I

Idonea of Leyburn (N. Yorks) 99

Ingram Intro. 5

Isaac of Chesterfield, D I96

Iseult former wife of Robert the smith I8oI8I, I86-I87

Itho 212

Ivo, abbot of Beauchief 203 n. 2

James Oates Intro. 19

Joan Bassett, lady 218 n. I

Joan daughter of Sir Robert of Lathom (Lancs) 66

Joanna of Alfreton, D Intro. 7

Joanna wife of John Ormond Intro. $8 n$

Jocelin of Stainsby, D 26 n. 4, 56 n. I, 90 n. I

John of Abbernun 35 n. 2

John, abbot of Beauchief Intro. 29

John of Annesley, N, knight Intro. 29

John Austin Intro. $I 6$

John Basset, knight 50 n. I, 218 n. I

John Blackiswalle, knight Intro. ${ }_{5}$

John Blythe of Norton, D Intro. 19

John Calton of Totley, D Intro. 18

John of the Cliffe, D $3^{8}$

John Croke Intro. 12

John Downham, abbot Intro. 22

John of Duffield, D I77

John Fanshawe (Faunchall) Intro. I4-I5

John Greenwood, alias Sheffield, abbot Intro. 12 , Intro. 23
John Moor of Greenhill, D Intro. 20

John at the new mill, SH i9

John of Normanton, D 219 n. I

John of Ridgeway, D, chaplain 217-218

John Rocester of Dore, D Intro. 6

John of Rotherham, SY $102-103$

John Sargant of Alfreton, D 75

John the smith 24, $3^{8}$

John son of Adam at the spring in Greenhill, D 55

John son of Isaac of Chesterfield, D I96

John son of Luke of Beeley, D I74

John son of Madoch Intro. II, I82

John son of Walter of Buildwas (Shrops) 220

John the swane son of Adam of Greenhill,

D Intro. $I 0,52$

John Swift, canon Intro. 22

John of Taddington, D 200

John Tonk 47

John of Wigley, D 217-220

John Wolaton 82

John of the wood 25

John Woodhouse, dean of St John, Chester 218 n. I

John Wykwall, vicar of Dronfield Intro. 13

Jordan of Attercliffe, $\mathrm{SH}$ II 3

Jordan Herring of Herringthorpe, D Royal Conf. 46

Juliana daughter of Adam the carter (of Brincliffe, SH) I29, I39, I4I

Laurence the smith IOI

Lettice wife of Andrew of Hooton, SY Io6I07

Lovechild, widow $5,3^{8}$

Lucius III, pope I

Lucy daughter of Robert of Alfreton, D 57

Luke son of Warin of Beeley, D I7I-I75, Royal Conf. 49

Madoch 182

Margaret of the Brom Intro. 2I

Margaret daughter of Walter the shepherd I47

Margery of Beeley, D, daughter of Robert, former dean of Beeley I70-I7I

Margery daughter of Luke of Beeley, D I75

Margery the former wife of Richard the nailer of Chesterfield, D 202

Margery widow of Ralph of Reresby, L Leake 8

Matilda of Ashover, D Intro. $2 I$ 
Matilda daughter of Gilbert of Hasland, D I92-I93

Matilda (Maud) of Louvetot, SH Intro. I5, Royal Conf. 39-40

Matilda mother of Simon I62

Matilda wife of Peter of the hurst 194

Matthew of Hathersage, D Intro. I4, I6II 62

Michael of Hathersage, D Intro. 20

Nicholas of Lathom (Lancs) 66

Nicholas of Longford Intro. I8-19

Nicholas son of John of Rotherham, SY IO2

Nicholas Strelley, knight Intro. 15 , Intro. 18 , Intro. 23

Nicholas Torald 22

Nigel of Lisurs Intro. 30

Nigel the smith 224

Nigel of Stokes Intro. 30

Norman father of William and John of Taddington, D 200

Odo (Eudes) Leneire 88

Odo (Eudes) son of John 204

Orayn mother of William the clerk of Saint John IgI

Osbert son of Richard of Hore I74, I75

Osbert of Wadsley, SY I45

Peter Intro. II, 4, $3^{8}$

Peter of Bradfield, SY I39-I4I

Peter of Goxhill (Lincs) I8 n. 2

Peter of the hurst I94

Peter at the mill of Bradway, D 35

Peter the weaver Intro. $I I, 26,38,9^{\circ}$

Ralph, abbot of Beauchief $30 \mathrm{n} .3$

Ralph Barker of Dore, D Intro. 9, Intro. 13, Intro. 19, 82, 218-219

Ralph Barre I of Teversal, N 203, Royal Conf. 45

Ralph Barre II son of Geoffrey Barre of Teversal, N 203

Ralph, clerk of Sheffield I43

Ralph the cobbler I8I

Ralph of Ecclesall, SH I20, I24-I25

Ralph of Fallinge, D I76-I78

Ralph Frescheville 219 n. I

Ralph of Freshmall Leake 7

Ralph of the Hospital 2II

Ralph Musard Intro. 8, Intro. 30, 222 n. 4, Royal Conf. $30^{-} 3^{2}$
Ralph Musard son of Ralph Musard Royal Conf. 33

Ralph, reeve of Wymeswold, L i6

Ralph of Reresby, L, husband of Margery I79, I83, I85, I88, Leake 8-9

Ralph of Scholes, SY I05

Ralph son of Geoffrey Barre 203 n. 2

Ralph son of Robert of Ecclesall, SH Intro. 8-9, Intro. I8, III, III $n .5$, II2-II6, I22-I 23

Ralph son of Robert of Reresby, L I83, I86I87

Ranulf $3^{-6}$, II, 38, 59, Royal Conf. I

Ranulf of Alfreton, D Intro. 5, Intro. $3 I$

Ranulf brother of Robert of Alfreton, D I2I5, 57

Ranulf son of William son of Robert of Alfreton, D 64, 76

Ranulf of Storthes, D 27, $3^{8}$

Reyner of Bullon (Boulogne?) I36

Richard Bars 82

Richard of Bernak (Cambs?), lord of Beighton, SY 163

Richard of Bernes, D I8I

Richard, bishop of Coventry Intro. 3, 3

Richard Costenoth I42-I44, I46

Richard Daniel Io9

Richard the ditcher Intro. $1 I$, I55

Richard Edward 38

Richard Everard 27

Richard of Glapwell, D Intro. 6, 204, 2II, 216

Richard the good smith I98, 200-20I

Richard of Hore (or Horegh) 22, 29, 38, I74-I75

Richard of the moor 21, 23, 38

Richard Musard Intro. 8 n

Richard the nailer of Chesterfield, D 202

Richard Oxley, knight Intro. $2 I$

Richard the redsmith of Swanwick, D 69

Richard of Scholes, SY 99, I00-IO2

Richard Scyvel I34

Richard the serjeant I33

Richard son of Adam 25

Richard son of Adam the cook of Sheffield Intro. $I I, \mathrm{I} 5 \mathrm{O}$

Richard son of Edward of Scholes, SY Ioo

Richard son of Gerard 136

Richard son of Hugh of Scholes, SY 95, 98, IO3

Richard son of Jordan of Attercliffe, $\mathrm{SH}$ I 13

Richard son of Richard Costenoth I42-I44

Richard son of Thoke Intro. II, I3I 
Richard son of William Daniel of Tideswell, D 107 , 109

Richard son of William of Glapwell, D 203, 205, 207-208, 2I 4

Richard son of William of Thorpe, SY ${ }_{103}$

Richard the squire 56

Richard Swappocke 34

Richard of Tapton, D 192

Robert Intro. $I I, 4,38$

Robert, abbot of Beauchief $I 75$ n. I

Robert of Alfreton son of William of Alfreton, D 8-IO, I2-I7, 38, 57, 64, 76, 89, Royal Conf. 5-8

Robert of Barley (Barlow, D) $218 \mathrm{n}$. I

Robert of Beeley, D i69-I7I

Robert Bele, miller Intro. I9

Robert of Bella Aqua Intro. 30

Robert Brito of Walton, D Intro. 6, I64, I89

Robert Chaworth Intro. 7

Robert of Childre 27, 38

Robert, clerk of Hooton, SY II 4

Robert, clerk of Masbrough, SY 98

Robert, clerk of Walton, D I9o, I96

Robert the cook 208

Robert, dean of Beeley and father of Susanna and Margery of Beeley I7I

Robert, dean of Darley, D I76-I77

Robert of England I29, I39-I4I, I5I

Robert Ferrers, 2nd earl of Derby Intro. 6

Robert the fletcher 30, 38, 49

Robert the forester 3, 27, 38

Robert of Furness, knight Intro. 6, Intro. ${ }^{6} 6$, Royal Conf. 34

Robert of the Greaves, D 20, 22, 38, 48

Robert of Grendun Intro. 30

Robert Hauselin (of Brincliffe, $\mathrm{SH}$ ) I28

Robert of Hooton son of William of Hooton Roberts, SY I IO

Robert Ladde, clerk of Burton 65

Robert of Lathom (Lancs), lord 24, 38, 66

Robert the mason I44

Robert of the mill of [Coal] Aston, D 38

Robert nephew of Robert of Scholes, SY 93-94

Robert Putrell (of Cotes, L) 59

Robert Pykard 42

Robert of Radclyffe, abbot of Beauchief 8384

Robert the redsmith of Swanwick, D 22, 38, 7I-73, 78

Robert of Reresby, L i8I, Leake 7, Leake 9

Robert Rivers, knight and rector of Eckington Intro. $2 I$
Robert Scarlet 27, 38

Robert the smith I80-I8I, I86-I87

Robert son of Alice and nephew of Robert 97

Robert son of Edwin of Chesterfield, D Intro. $I I$, I 99

Robert son of Gilbert of Perlethorpe, N 9596

Robert son of Godric of Darley, D Intro. II, I 69

Robert son of Hugh of Glapwell, D 206, 2 IO, $2 \mathrm{I} 2$

Robert son of Hugh of Little Sheffield, SH I 26

Robert son of John of Wigley, D 218

Robert son of John (of Wymeswold, L) 65

Robert son of Osbert of Wadsley, SY I45

Robert son of Ralph of Ecclesall, SH I2 I

Robert, knight, son of Sir Ralph of Ecclesall, SH Intro. I8-I9, II9

Robert son of Ralph of Reresby, L I79, I85I 88

Robert son of Ranulf Intro. 2, Intro. 4-5, Intro. ${ }^{O} O-12$, Intro. 24 , Intro. $31,3^{-6}$, II, 38, 59, 64, 76, Royal Conf. I-3

Robert son of Richard of Lathom (Lancs) Intro. 7

Robert son of Richard the good smith 200

Robert son of Robert Brito of Walton, D I89

Robert son of Robert of Masbrough, SY 96

Robert son of Robert Wyden of Wadsley, SY I44

Robert son of Roger of Dronfield, D II5

Robert son of Walter of Brampton, D Intro. $28 n$

Robert son of Warin of Beeley, D I65

Robert son of Wido (of Wadsley, SY) I45146

Robert son of William of Alfreton, D 8-IO, I2- $17,34,38,64,76,89$

Robert son of William of Hooton, SY IIO

Robert son of William of Wymeswold, L 62

Robert Swift Intro. 19

Robert of Wigley, D, senior 217

Robert Wyden I44

Roger 3, 205

Roger, abbot of Beauchief 35 n. 3, 203 n. 2

Roger of the alder-grove I47

Roger of Alfreton, D I2, I3, I5, 57-58, 60, 64,76

Roger Barker Intro. 18

Roger the bercher 22, 38, 80

Roger of Birley Intro. 29 
Roger of Bradway, D 35

Roger Cade I9I

Roger of Chesterfield, D, knight Intro. 20

Roger the clerk, son of Hugh of Glapwell, D (see Roger son of Hugh)

Roger of Dronfield, D I I5

Roger Eyre Intro. 19

Roger of Marcham, N I79, I86-I87, Leake 7

Roger Mons 22, $3^{8}$

Roger of Poitou (France) Intro. $5^{n}$

Roger Pycard 42

Roger of Ridding, D 9, 38

Roger Ruffus 20I

Roger the smith of Birchwood, D 38, 68

Roger son of Adam of Glapwell, D 209 n. I, 213

Roger son of Arnold 204

Roger son of Hugh of Glapwell, D, and clerk 206, 210,212

Roger son of Hugh Hauselin (of Little Sheffield, $\mathrm{SH}$ ) 558

Roger son of Juliana the carter 129

Roger son of Peter of Bradfield, SY I39-I4I

Roger son of Richard the squire of Norton, D 53

Roger son of William 209

Roger son of William of Hollins, $\mathrm{SH}_{\mathrm{I}_{5}-}$ I54, I58, 209

Roger of Wadsley, SY 145

Roger of Wigley, D 217

Roscelin of Bromp (Broom Hall, SH) 67, I30

Salinwell 38

Samson 27, $3^{8}$

Serlo of Pleasley, D Intro. 6, I82

Serlo son of Warin of Beeley, D Intro. 6, I64, I67-I68, Royal Conf. 50

Siggrit daughter of Henry of Scholes, SY 94

Simon, lord 204

Simon of Cromwell, N Intro. 3o, 2I4

Simon of Goxhill (Lincs) I62

Simon son of Henry son of Gunnild of Sheffield Intro. II, I 48

Simon son of Hugh of Glapwell, D ${ }_{1} 6$ n. I, 204, 209, 2I2, 2I4

Simon son of Matthew I62

Simon son of Ralph of Fallinge, D I77-I78

Simon son of Rocelin of Bromp (Broom Hall, SH) I3o

Simon of the Storthes, D 26, 38, 82

Solon I35

Stephen Nevil 62
Stephen son of Stephen the parson of Chesterfield, D I98

Suard $3^{8}$

Susanna of Beeley, D, daughter of Robert, former dean of Beeley I70-I7I, I75

Sweyn 204

Sweyn of Boulogne II4

Sybil the weaver I80, I8I, I86-I87

Theobald of Valoines I2 n. I

Thoke I3I

Thomas of Alfreton Intro. 7, Intro. 12

Thomas of Beeley, D Leake 6

Thomas of Bella Aqua (SY) Iog

Thomas of Bradwell, D I05

Thomas of the Chamber (de Camera) Intro. 29

Thomas Chauz of Brampton, D Leake 5

Thomas Chaworth I, lord Intro. 7 , Intro. 17 , Intro. $29,17-43,45,47-49,52-53,56$, $58,60,66-68,70-71,87$

Thomas Chaworth II, lord Intro. 7, Intro. $28,44,46,6$ I

Thomas Chaworth III, lord Intro. 7, 50, $83-$ 86

Thomas Chaworth IV, lord 218, 219

Thomas Chaworth I or II, lord Intro. 17 , Intro. 29, 5I, 54, 72-73, 77-8I

Thomas Chaworth I, II, or III, lord Intro. $32,55,88$

Thomas of Dronfield Intro. I2n

Thomas the forester of Alfreton, D 74

Thomas of Furnival I, lord Intro. 8 , Intro. I5, Royal Conf. 4I-42

Thomas of Furnival II, lord Royal Conf. 42

Thomas Gilbert, canon Intro. 29

Thomas Gory 54

Thomas Greenwood Intro. 19

Thomas Gyleson of the Greaves, D I75 n. I

Thomas Hilde I99

Thomas North Intro. ${ }^{1} 5^{-16}$

Thomas Rodes, chaplain 219 n. I

Thomas of Romerthwert 200

Thomas son of Adam at the spring in Greenhill, D 55

Thomas son of Hugh of the wood 2I, $3^{8}$

Thomas son of John of the wood 25, $3^{8}$

Thomas son of Nigel the smith 224

Thomas son of Richard the good smith 200

Thomas son of Richard the redsmith 69

Thomas son of Robert of Masbrough, SY 96

Thomas son of Roger of Gotham, N I8 
Thomas son of William of Glapwell, D 2I5

Thomas of the Wood I8, 28, 33

Uchtred Intro. $11, \mathrm{I} 76-\mathrm{I} 77$

Walter the baker $134^{-1} 3^{6}$

Walter Barry of Teversal, N Intro. 6

Walter brother of Daniel the butler I04

Walter of Buildwas (Shrops) 220

Walter Chauz, son of Thomas Chauz of Brampton, D Intro. 9, Leake 5

Walter of Furness Royal Conf. 34

Walter the shepherd I47

Walter son of Robert of Furness Intro. I $6 n$

Walter of Ufton, D $7 \mathrm{I}^{-} 73$

Warin of Beeley, D Intro. 6, Intro. ${ }_{15}, \mathrm{I}_{64}-$ I68, I7 $\mathrm{I}-\mathrm{I} 72$

Warin son of Robert of Beeley, D I69

Weremund Intro. $I I, 203,205,208$

Wido son of Roger of Wadsley, SY I45

William ı66, 209

William, abbot of Beauchief 65

William, abbot of Welbeck, N $137 n .3$

William of the Barkhouse of Norton, D Intro. 19, 218-219

William Barry of Teversal, N Intro. 16 , 203, 222-224, Royal Conf. 43

William Barry son of Ralph Barry of Teversal, N Royal Conf. 45

William Blackwall Intro. $15-16$

William Bolles Intro. 17 , Intro. 23

William Brewer 200

William of Briges I92-I94

William of Brincliffe, $\mathrm{SH}_{\text {I28 }}$

William Chaworth, knight, son of Sir Thomas Chaworth Intro. 7, 44, 6I, 909I

William the clerk of Saint John I9I

William the cook 56

William of Cressy (France) Intro. 30, I20, I24

William Dolphin of Eckington parish, D Intro. 20

William of Dronfield, D Intro. 9, I59

William of Folkingham, abbot of Beauchief 30 n. 3, 99, Leake 8-9

William of Glapwell, D 203, 205, 207-208

William of the Greaves 175 n. I

William of Gringley, N, knight Intro. 21
William Holland Intro. 15

William of Hollins, SH I5O, I52-I55, I57

William of Hooton Roberts I Io

William Jorrs 63

William Kitchen (Kychyne) Intro. I2

William of Little Sheffield, SH 129

William of Lovetot (France) Intro. 6, I29 $n$. 2

William of Meynell [Langley], D I59

William the merchant of Sheffield I47, I57

William of Myrie I77

William of Normanton, D I92

William Picard 5I

William of Retford (Radeford), tanner Intro. 19-20

William son of Andrew of Hooton, SY Io6

William son of Daniel the butler I04

William son of Gamel of Ecclesall, SH Intro. II, II 7

William son of Geoffrey of Stanley, N 222, 225-226, Royal Conf. 45

William son of Gilbert of Catcliff, SY, $196 n$. I

William son of Hugh Hauselin of Little Sheffield, SH I26-I27, I49

William son of Norman of Taddington, D 200

William son of Ralph Barry of Teversal, N Royal Conf. 45

William son of Richard of Dore, D I02

William son of Richard of Glapwell, D 2 I6

William son of Richard the squire 56

William son of Robert of Alfreton, D 7, II, 38, 64, 76, Royal Conf. 4

William son of Sunun 49

William of Stainsby, D, knight Intro. 29

William of Stone of Harewood Intro. 15

William Swift Intro. 19

William the tanner of Sheffield Intro. II, I34-I35, I48

William of Thorney, dean of Lincoln cathedral Intro. $28 n, 217 n .3$

William of Thorpe (Hesley), SY IO3

William Tinett of [Norton] Woodseats, D I8, 28, 33, 38, 50

William West, knight Intro. 24

William Widdowson Intro. 22

Winnora of Cockshutt 2I, 23, $3^{8}$ 


\section{ii) Witnesses}

Note: the witnesses were always male.

A., abbot of Welbeck, N 59, 63

A., prior of Worksop, N 59

Adam, abbot of Welbeck, $\mathrm{N}_{5}^{-6}$, I I

Adam of Berne, SY 103

Adam of Birchett, D I43

Adam le Blunt Intro. 29

Adam, chaplain of Normanton, D Io

Adam, chaplain of Rotherham, SY I05

Adam, chaplain of Wentworth, SY 97

Adam, clerk of Sheffield I57

Adam the cook of Sheffield I5O-I5I, I54-I55

Adam of Everingham (East Riding), knight and lord of Stainborough and Rockley, SY I8, 33, 39-4I, 44, 6I

Adam of Gotham, N 50

Adam of Harthill, D I04, I67

Adam of Kucton 5

Adam of Normanville (France) Io6

Adam of Reresby, L 37, 4I, 46, 8I

Adam of Ronnesley I75

Adam son of Phillip of Huston 4, I I

Adam of Stretton, D 3 , I I, 63

Adam of Taptover I88

Adam of Wadsley, SY I49

Adam of Wandell I27

Adam of the wood (de bosco) in Sheffield Intro. 29, I34-I36, I39-I4I, I43, I47I48, I54

Alan of Edelwasdeleia I64

Alan son of Richard of Glapwell, D 206207, 210

Albinus, abbot of Derby Intro. 3, 3-4

Alexander of Birchwood, D 75

Andrew of Hooton, SY 108

Andrew son of Richard of Glapwell, D 206207, 210

Arnold of Wymeswold, L 62

\section{Daniel, chaplain of Sheffield I39, I5I}

Edmund of Ainecourt (or Deincourt), knight and lord of several local manors $3^{8}$

Edmund of Wasteneys (France), knight and lord of Todwick, SY i Io

Egidio (see Giles)

Ellis of Ecclesall, SH I2 I-I23

Ermemot of Wenham (Suffolk) IO4

Eudes (see Odo)
Eustace clerk of the lord of Sheffield io8, I30, I49

Eustace of Lilleshall (Shrops), Brother 3-4

Eustace parson of Handsworth, SY I32-I33

Eustace son of Hugh 4

Galfrid (see Geoffrey)

Gamel son of Serlo I34-I36, I47-I48

Geoffrey Barry, lord of Teversal, N 66

Geoffrey brother of Henry of Shelton, N 6

Geoffrey, clerk of Beighton, D 23, 6o

Geoffrey, clerk of Brampton, D i64

Geoffrey, clerk of Osberton, $N_{7}$

Geoffrey, clerk of Sulcholm 59

Geoffrey of Hodsock, N I2O, I24

Geoffrey of Musters 209, 222 n. 4

Geoffrey son of Stephen of Westwold (i.e. Wymeswold, L?) 62, 65

Geoffrey son of T. of Lond' 59

Geoffrey son of Warin of Beeley, D I65-I66

German of Mortomley, SY I49

Gervase of Bernaby II I

Gervase of Bernak (Barnack, Cambs?), lord of Beighton, D 24, 34-35, 43, I06, Io9

Gervase of Kenilworth (Warwicks), magister 59

Gilbert of Bernston 4

Gilbert, prior of Blyth, N I24

Gilbert of Sucton 4

Giles of Meynell (lord of Meynell Langley, D) Intro. 29, 38, 90

Giles of Rossale (Shrops) 67, 72-74, 78

Hacon the reeve 5

Hasculphus Musard 222 n. 4

Henry of Berengerville (or Bergerville) 7, 63, 92

Henry of Birchwood, D 57, 66

Henry of Brailsford, D, knight Intro. I2, 36 , $3^{8,4}$, , I83-I84, I87

Henry, clerk of Horchent 63

Henry Daate 50

Henry of Edwalton, $\mathrm{N}$ I2-I3

Henry Lecard 102

Henry of Longcroft 69, 7I, 73, 79-80, 87

Henry of Masbrough, SY 95-96

Henry of Newbold, D 28

Henry of Pierrepoint, lord of Holme Pierrepont, N, and Langwith, D 26, 90

Henry of Shelton, N 6 
Henry son of Godolf I 3 I

Henry son of Roger of Wadsley, SY I20, I24, I 45

Henry son of Stephen of Harley, SY 103

Henry of Spina (i.e. thorn) I44

Henry of Stead, SY 103

Henry of Tankersley, SY I2I-I23, I56

Henry of Tinsley, SY ıо , Io9

Henry Wylte Intro. 29

Herard of Bernest 63

Hugh of Birchett, D 42

Hugh of Brom (Broom Hall, SH) iI7, I3o, I33

Hugh of the Canons Intro. 29, 27, 38, 67-68, 70,72

Hugh of Chesterfield, D, magister I64

Hugh of Dronfield, D I64

Hugh Hauselin (of Little Sheffield, SH) Intro. $19, \mathrm{II}_{7}, \mathrm{I}_{30} \mathrm{I} \mathrm{I}^{2}, \mathrm{I}_{4} 6$

Hugh of Huletotes 92

Hugh Kent ${ }^{4} 8$

Hugh of Linacre, D Intro. 29, I8-I9, 22, $3^{2-} 33,3^{6-4}$ I, 44, 46, 5I, 54-55, 6I, 8I, I83-I84, I87, 222, Leake 5, Leake 8-9

Hugh Lunt I35

Hugh, parson of Dronfield, D 204, 208, 2 I I

Hugh of Sandiacre, D 7

Hugh son of Godolf I 3 I

Hugh son of Henry 92

Hugh son of Peter of the Woodhouse, D I7, $2 \mathrm{I}$

Hugh, son of Robert, clerk of Walton, D 209

Hugh of Southwell, N 5,7

Hugh of Tankersley, SY 98

Hugh of Tuxford, N, clerk 53, I88, Leake 8-9

Hugh of Ulgerthorp (Oakerthorpe), D 68, $72,74,77-80$

Hugh of Wadsley, SY 32 , I05, I I4, I30, I32, I 45, I 49, I 56

Hugh of Windhill, SY 103

Hugh of Woodhouse $23^{-24}, 43,58,98$, II6

Ingelram or Ingram of Brampton, D $204 \mathrm{n}$. 2, 209 n. I, 2I I n. I

Ivan of Prestwold, L 63

Jeremy of Leysers 94

John of Ancourt (France; otherwise Ayencourt, Deyncourt, Deynecourt, Eyncourt, Eynecourt, or Eynecourt), knight I8-I9, 22, 28, 33, 37-4I, 44, 5I, 54,6 I, 7I, 8I

John of Annesley, N, lord Intro. 29, 26-27, $3^{8,90}$

John Bard Leake 2

John Basset, lord $5^{\circ}$

John Bate I83-I84, I87

John of the Beyle I59

John of Birchitt, D Intro. II, 20, 24-25, 29, $3^{\mathrm{I}-} 3^{2}, 35,4^{2-43}, 45,4^{8-49}, 5^{2-53}, 5^{6}$, Leake 8-9

John of Brampton, D Leake 5

John of Brimington, D Intro. 29, I8, 22, 26, 3o, 33, 38-39, 40, 5I, 53, 55, 90, I88, Leake 8-9

John Broune of [Coal] Aston, D 54

John Buk, lord $3 \mathrm{I}$

John, chaplain of Campsey Ash (Suffolk) I6, 64,76

John, chaplain of Ecclesfield, SY I2 I-I23

John, chaplain of Wymeswold, L 63

John the clerk I3, I6, 64, 76

John, clerk of Stubley, D Intro. II, I9, 20, 22, 25, 28, 5I, 53, 55

John, clerk of Wentworth, SY Ioo

John, clerk of Wymeswold, L I2

John of the Cliff, D I29

John, constable of Sheffield ${ }_{5} 6$

John Daincurth (otherwise de Heincurt, Deynkurt, or de Eincuria) 206-208, 2IO, 222-223

John of Darley, D I04

John Dorli, lord 95-96, 98

John Friend I40-I4I, I 57

John of the hall of Alfreton, D 74, 87

John of Heriz, knight and lord of Tibshelf and South Wingfield, D Intro. 29, 26, $3^{8}, 78,80,90,223$

John of Huntingfield (Suffolk) I5

John Ingram 65

John of Langley, D I I8

John of Midhope, SY I49, I 56

John of Orby (Lincs) 4

John of Peito in Chesterfield, D I88

John the Poher, brother of Ralph 9-IO, I2I6, 64, 76

John Putrell of Wymeswold, L 62

John of Rossington, SY Intro. 29

John the servant of Kimberworth, SY 93

John of Siwoldby, L 62

John son of Adam the spenser 65

John son of Giles, parson of Foxton, L I6

John son of Peter of Birchett, D i 6 
John son of Richard of Glapwell, D 206207, 210

John son of Sweyn 137-I38

John of the Stead, SY IO2

John of Vilers in Marnham, N 3I, 34, 62

John of Wigley, D 46, 54

John of Wiresdale (Lancs) I02

Jordan of Apetoft II5

Jordan, chaplain of Norton, D 92

Jordan, chaplain of Sheffield II7-I I8, I26

Jordan Foliot 120, I24

Lambekyn Gamel son of Serlo I34

Lambert the dyer of Sheffield I50-I53

Laurence of Chaworth (France), knight $3^{8}$

Lisiard, magister 59

Matthew, abbot of Rufford, N 59

Matthew of Bakewell, D, priest I65-166

Matthew, canon of Welbeck, N $137^{-1} 3^{8}$

Matthew of Eston 3

Matthew of Hathersage, D I67

Matthew of Holme, D 203, 205

Matthew son of Hugh and brother of Ralph 3-4, I I

Matthew of Welbeck, N, Brother 5

Michael(?) of Holme, D Leake 5

Michael son of Hugh, parson of Dronfield, D 204, 2II

Nicholas of Bakewell, D 82

Nicholas of Birchitt, D I64

Nicholas of Boby, knight 62

Nicholas of Holm, D Leake 5

Nicholas, lord of [Meynell] Langley, D 89, 204, 2 II

Nicholas son of Nicholas of Wortley, SY 94

Nicholas Wake, knight Intro. 29, 38

Nicholas of Woodhouse 92, IOI

Nicholas of Wortley, SY 94, I2 I-I23, I56

Nigel of Lisurs Intro. 30

Odo 3

Odo son of Ralph 63

Osbert Thakall 93

Osbert of Wachesh I6

Peter of Alfreton, D 74

Peter of Bamford, D I75

Peter of Barnes, D Intro. II, 20, 23, 25, 29, $3^{2}, 4^{2}, 45,4^{8-} 49,5^{2-}-53,55^{-5} 6,60,70$, Leake 5, Leake 8

Peter of Birchitt, D Intro. $I I, \mathrm{I} 7,2 \mathrm{I}, 34,5^{8}$, 88, II2-II3, II5, I26-I27, I42, I44, I46
Peter of Brimington, D $4 \mathrm{I}$

Peter, chaplain of Glapwell, D 206-207, 2 IO

Peter of Doncaster, SY, magister 59

Peter of Harthill, D I65-I66

Peter of Harthill, D or SY, brother of Robert 5-7, 92, 203, 208

Peter Herries Leake 9

Peter of Kilnhurst, SY I37-I 38

Peter of Leys (Norton Lees), D 30

Peter Payne of Norton, D 20

Peter of the Peak I35, I48

Peter of Roydes i Io

Peter of the Woodhouse 17, I26

Phillip of Huletotes 7

Phillip son of Gerard of Styrrup, N I I

Radolf (see Ralph)

Ralph of Avers (France) I20, I24

Ralph Barri (of Teversal, N) 203

Ralph Basset, canon of Rocester (Staffs) I64

Ralph Bercher 82

Ralph of Bredon, L 89

Ralph of the Cemetery II7-II8, I3I

Ralph the clerk 98, I05, I28

Ralph, clerk of Sheffield ıо6, Iп-II3, II6, I26-I28, I42, I 46

Ralph, clerk of Wentworth, SY 93

Ralph of Ecclesall, SH, lord 34-35, 93, 97, IOI, IO5, IO9, I 45

Ralph Hauselyn (of Little Sheffield, SH) I 6

Ralph of Nidhing I64

Ralph of Normanvile (France), lord I07, I2I-I23

Ralph the Poer 8-IO, I2-I3

Ralph, rector of the church of Heckington (Lincs) Io

Ralph of Reresby, L 23, 37, 81

Ralph the seneschal 5-6

Ralph Silvanus of Thorpe, SY 203, 205

Ralph son of Ralph 63

Ralph son of Richard of Brampton, D 222

Ralph son of Robert of Ecclesall, SH 94

Ralph son of Hugh 3-4, II, 63, 203, 208

Ralph of Tideswell, D, magister I04

Ralph of Wingfield, D 75

Ralph of Wortley, SY II I-II3

Ranulph of Acton II3

Ranulph of Jorr 64, 76

Ranulph the seneschal of Sheffield in 6

Ranulph son of William of Alfreton, D 222

Ranulph of Swanwick, D 73

Ranulph, vicar of Norton, D 49, I26-I27

Ranulph of Wadsley, SY, lord 66, 9o 
Reginald, abbot of Roche, SY I20, I24

Reginald of Bullon (Boulogne?) I36, I48

Reginald of Colwick, N I24

Reginald of Glewit I20

Reginald of the Hollins, SH 77

Reginald of the island 63

Remigius, prior of Shelford, N 59

Reyner Bullon (Boulogne?) I34, I47

Reyner, clerk of Sheffield I28, I43

Reyner, parson of Treeton, SY 95-96

Richard, abbot of Welbeck, N I37-I38, 222

Richard the chaplain 7

Richard, chaplain of Ecclesfield, SY I2 I-I23

Richard, chaplain of Norton, D 92, I65

Richard, chaplain of Rawmarsh, SY $137-$ I 38

Richard, chaplain of Sheffield Io8

Richard, clerk of Marnham, N 3 I

Richard of [Coal] Aston, D I42, I46

Richard the cook I 36

Richard Corbard of Sheffield I29

Richard the dean $5^{-6}$

Richard, despenser of Alfreton, D 9-IO, I2I3, I5-I6, 64, 76

Richard of Edensor, D I04, I08, I67

Richard of Finningley, N II

Richard of Flintham, N 107, I58

Richard of Furness, knight and lord of Beighton, D I8, 33, 39-41

Richard of Gotham, N Io6

Richard of the Hall 213-2I4

Richard of Handley, D I42, I46

Richard of Harthill, SY 8

Richard of Heeley, SH I29

Richard of Lavender (Lavendon, Bucks?) I36, I47

Richard of Leake, N 62

Richard of Loversall, SY I IO

Richard, marshal of Norton, D 42, 49, 56

Richard Peche I04

Richard, smith of Thorpe, SY Ioo

Richard son of Adam I25

Richard son of Arthur II4

Richard son of Henry of Thorpe, SY Ioo

Richard son of William of Glapwell, D 206, 209-210, 222

Richard Torkard of Sheffield I5I

Richard Walteroc' I35, I48

Robert of Abney, D I94

Robert of Aldwark, SY II6, I26-I27, I58

Robert of Anjou 63

Robert the archer I04

Robert of Belgrave, L 62
Robert Blanckaim the clerk 65

Robert the Blount 88

Robert of Blyth the parson of Misterton (Lincs) I08, I32

Robert the Breton, seneschal of Hallamshire I33

Robert Brien 76

Robert of Briminton 222

Robert Brito (otherwise le Breton or le Bretun) of Walton, D 203-205, 208209, 2II, 222

Robert of Brom (Broom Hall, SH) Intro. 29, I28, I43, I57

Robert brother of Peter of Harthill, D or SY $6,7,203,208$

Robert brother of Roger, clerk of Glapwell, D 209

Robert brother of Simon of Glapwell, D 2 I I

Robert Bulmer 36

Robert, chaplain of Alfreton, D 8, Io, 89

Robert, chaplain of Campsey Ash (Suffolk) I $6,64,76$

Robert, clerk of Totley, D io8

Robert, clerk of Walton, D 203-204, 208209, 2I I

Robert of the Cliff, D I52-I53

Robert, dean of Darley, D ı04, I64, I76

Robert of Dethick (Dencokes, Deverk), D, knight I83-I84, I87

Robert of Ecclesall, SH, knight Intro. 10 , I8, $33,37^{-38}, 4^{\text {O }, ~ I I O, ~ I 33, ~ I 49, ~ I 54 ~}$

Robert Frank I88

Robert the forester $5^{8}$

Robert of Gratton, D Leake 6

Robert the Graunt (of Langwith, D) Intro. 29, 23, 26, 30, 32, 38, 42, 56, 60, I88, 2I3-2I4, Leake 5, Leake 8-9

Robert of Greenhill, D 87

Robert of Grendun Intro. 30

Robert Harang 2I3-2I4

Robert Hasard I39-I4I

Robert Hauselin (of Little Sheffield, SH) I I3, II 6, I28, I39-I4I, I57-I58

Robert of Hope, D I65-166

Robert of Jorr 63

Robert of Kelesehold 89

Robert of Knyveton, D Leake 6

Robert of Mattersey, N I2

Robert of Muffield of Brampton, D Leake 6

Robert of Munteney (France), lord of Cowley and Shirecliffe, SY II3

Robert, nephew of Peter and Robert of Harthill, D or SY 7 
Robert the official of Westhind, magister 95-96

Robert of Ogston, D I7

Robert Picot I6

Robert, prior of Worksop, N I2O, I24

Robert Putrell of Wymeswold, L I2-I3, I6, $57,64,76$

Robert of Pyrhohe (Pirehill, Staffs?) I5

Robert of Rearsby or Reresby, L 9o, Leake 5

Robert Ro 5

Robert Sautcheverel, knight Intro. 29, 38

Robert Scarlet 27, 32, 67-68, 70, 72-73, 78, 9o

Robert Seller of Rotherham, SY IO2

Robert, seneschal of Sheffield II4, I2O, I24

Robert son of Brian $\mathrm{I}_{5}, 64,76$

Robert son of Henry 92

Robert son of Hugh of Glapwell, D 204, 208, 2II

Robert son of Ranulph and father of William I

Robert son of Roger of Aldwark, SY I07

Robert son of Roger of Ridding, D 75

Robert son of Wido of Wadsley, SY I I4, I3I

Robert son of William 97

Robert son of William of Alfreton, D 64, 76, I 67, 205, 222

Robert of Stanton, D I67

Robert of Swanwick, D 69

Robert of Thorpe, SY 63

Robert of Wadsley, SY, knight 44, 6r

Robert of Warnwike $6_{5}$

Robert of Watnall, N, lord 66

Robert of Wentworth, SY 94, I05

Robert of Willoughby, $\mathrm{L}_{5}$

Robert of Wombwell, SY Io9

Robert of Woodhouse 98, I03, IO5

Roger, abbot of Beauchief 66

Roger of Aldwark, SY I33

Roger of Alfreton, D 7, 9-IO, I4-I6, Io8, I30

Roger (I) of Ayncourt (France; or Heinecurt,

Eynecurt, Eincurth) 203, 209, 222

Roger (2) of Ayncourt (France; or Eynecourt) 66

Roger Bate 2I4

Roger of Berche io6

Roger of Birchwood 7

Roger of Brailsford, knight and rector of the church of Dronfield, D I8, 33, 38-4I, 44,6 I

Roger of Brecton 38
Roger (I) Breton or le Breton or le Bret I8, 22, 28, 33, 37-4I, 46, 5I, 54, 7I, 8I, I83I84, I87, Leake 8, Leake 9

Roger (2) le Bret 223

Roger (3) le Breton 223

Roger (4) le Brett, knight 46

Roger brother of Simon of Glapwell, D 204

$$
\text { n. 2, 2II }
$$

Roger, carpenter of Norton, D 30, 48, 53

Roger chaplain I82

Roger, clerk of Glapwell, D see Roger son of Hugh

Roger, clerk of Sheffield I64

Roger, clerk of Wymeswold, L 62

Roger of the Cliff, D 25

Roger of Cuckney, N I37-I38

Roger of Duckmanton, D 38

Roger of Fimeleya of Scholes, SY 92

Roger of Fletburgh in Norton, D 3I, 52

Roger of Fungl' 6

Roger of the Green in Norton, D 55

Roger Hauselin (of Little Sheffield, SH) Intro. 29, I28-I29, I39-I4I, I5O, I54I55, I57

Roger of Hollins, $\mathrm{SH}_{\text {I }} 3$, I28

Roger of Mattersey, N I2-I3, I20, I24

Roger of Newhouse, Brother 5

Roger of Ollerton, N 75

Roger of Osbaston, $\mathrm{L}_{57}$

Roger of Padley, D 50

Roger the Poer 209

Roger, rector of half of the church of Rotherham, SY IIO

Roger of Ridding, D 75

Roger of Sidenhale 206-207, 210, 222

Roger of Somervill 27, 56, 6o, 66

Roger son of Hugh of Glapwell, D, and clerk 204-205, 208, 2II

Roger son of Nicholas of Langley, D 204, 2 I I

Roger son of Ralph 4

Roger son of Reyner (or Reynes) of Aldwark, SY 95, I2 I-I23

Roger son of William 203

Roger of Swanwick, D 74, 8o

Roger of Ufton, D 69

Roger of Wadsley, SY I45

Serlo of Beeley, D 7-8

Serlo the chaplain I82

Serlo of Pleasley, D 3

Simon brother of Robert of Brimintun, D 209 
Simon, chaplain of Wortley, SY 94

Simon, clerk of Greenhill, D 78

Simon of Cromwell, N Intro. 30

Simon Friend I34, I35, I48

Simon of Greenhill, D 36, 77

Simon of Reresby (L or Lincs) I8, 22, 33, 39, 40

Simon son of Hugh of Glapwell, D 203-208, 2IO-2II, 2I3, 222

Stephen, abbot of Beauchief I6

Stephen of Bella Aqua, lord of Rawmarsh, SY Ioo

Stephen of Birchwood, D 8

Stephen of Birley, SY $9^{8}$

Stephen brother of Eustace and son of Hugh 4

Stephen the Eyr I9, 37, 38, 46, 54, 8I, I83I 84, I87

Stephen of Harley, SY 94, I03

Stephen the Joesu I54

Stephen Manluel (Meynell Langley, D?) 57

Swaro(?) the Buliona II4

Sweyn of Heriz 8

\section{T. of Lond' 59}

Thomas, lord $9 \mathrm{I}$

Thomas Barbot (Brabot Hall, Greasbrough, SY) $93,97-98$, IO2, I2 I-I23

Thomas of Bella Aqua (de Beleuu), lord of Rawmarsh, SY Io6

Thomas of Bradfield, SY 9, Io, I2-I3, I5, $57,64,76$

Thomas of Brampton, D 2I, 88

Thomas the Breton IIo

Thomas Brom (Broom Hall, SH) I44

Thomas Chaworth, knight 62, II5, Leake 5

Thomas, clerk of [Dronfield] Woodhouse, D Intro. $I I, 20,24^{-25}, 29^{-} 3^{I}, 35,42,45$, 48-49, 52, 53, 88, III-II 2, II5, Leake 5

Thomas, clerk of Morton, D 24, 27, 42

Thomas, clerk of Wadswick (Wilts) 49

Thomas Doylly Iog

Thomas Foljambe of Tideswell, D, lord 24, $35,45,70$, Io9

Thomas of Furnival (France), knight and lord of Hallamshire $18,33,38,40,44$, 6I, III-II3

Thomas of Gotham, N I52-I53

Thomas of Gunton (Suffolk) I5, 64, 76

Thomas Gylesonne of the Greaves in Beeley, D 175

Thomas of Hazelhurst, D 35

Thomas of Heton 25
Thomas of Huntingfield (Suffolk) I5

Thomas of Leys (Norton Lees, D) Intro. II, I7, 2I-22, 28-3I , 43, 5I 52, 57, 88, III, II5-II6, I26-I27

Thomas of Masbrough, SY 93

Thomas of Mounteney (France), lord of Cowley, SY and Shirecliffe, SH Io9

Thomas of the Peak 64,76

Thomas of Saint Quentin (France) I20, I24

Thomas Selweyn 9-10

Thomas serjeant I5I

Thomas of Sheffield I 55

Thomas son of Hugh the parson of Dronfield, D 204, 2 II

Thomas son of William of Glapwell, D 213$2 \mathrm{I} 4$

Thomas of Stannington, SY I44-I45

Thomas of Wadshelf, D 88

Thomas of Wheatcroft $137^{-1} 3^{8}$

Thomas of the wood of Sheffield II8, I29, I3I, I50-I5I, I54-I55

Thurstan, abbot of Garendon, L 59

Vicarius, magister 59

Walter of Ancourt, parson of Morton, D 208

Walter the baker 148

Walter of Bringhale (see also Walter of Mighale) Leake 9

Walter of Campo Remigii I49

Walter, clerk of Osbaston, L 4

Walter, dean of Stretton, D 4

Walter the despenser I64

Walter Dun of Dronfield, D 204, 2I I

Walter of Easthwaite (lord) I2-I3

Walter of Elmton, D 50

Walter of Goxhill (Lincs), knight I8, 3I, 33, $36,39-4 \mathrm{I}$

Walter of Kanrenn I3o

Walter of Kibuf (lord) 6o

Walter of Lindsey (Lincs) I59

Walter of Mighale (see also Walter of Bringhale) Leake 8

Walter the physician (medicus), magister 4

Walter of Southwell, $\mathrm{N}_{5}$

Walter of Ufton, D $32,36,46,66,68,79^{-80}$, 9o

Warin of Beeley, D I65-i66

William, abbot of Welbeck, N I20, I24

William of Adderley (Shrops or Staffs) 82

William of Alfreton, D I3I

William of Arnehall (Darnall?, SH) I43 
William of Aubeny, lord 34

William Basset I04, I76, I9I, 222

William le Bret (I) 223

William le Bret (2) (or le Brett, de Brett, le Brect, le Breton) I8-I9, 22, 28, 33, 364I, 44, 46, 5I, 6I, 7I, 8I, IO7

William Brom (Broom Hall, SH) I58

William Bulmer 71, 87

William of Burton 6

William of the Chamber, lord I44-I45

William, chaplain of Sheffield i 8

William of Chatsworth, D I65, I75

William Chaworth, lord 27, 34, $5^{8}$

William Clarell (of Aldwark, SY), knight i Io

William, clerk of Scholes, SY 93

William Colt 7o, 72-73

William the cook 5

William of Cressy Intro. 30

William the dagge IO4

William of Darley, D IO4

William Foljambe 45, Iog, Leake 8-9

William the forester 27

William Fraunceys 28, 77, 79

William of Gotham, $\mathrm{N}_{35}, 43,88$, Io6, I I III 3 , II 6

William Hauselin (of Little Sheffield, SH) I 29, I 50, I 54

William of Hazlebarrow, D 54

William of Heriz 222

William of Hollins, SH I4I

William of Hucknall, D 2 I3-2I4

William of Huntingfield (Suffolk) I5-I6

William the Latemer I07

William of Little Sheffield, SH I29

William of Litton, D I65-I66

William Matiney of Gravesend (Kent) 23, $25,29,48-49,70$

William of Matynesby (lord) 60

William of Meadow Hall, SY 93, 98

William of Meynell, lord of Meynell Langley, D Intro. 29, 38, 204, 2I I, 222

William of the moor I 29

William of Mundisder IOI, IO2

William Norm' (Normannicus?), magister 59

William, parson of Pleasley, D 203, 208

William Peck (or Pice, Pid', Pitt, Pyce) 26$27,56, \mathrm{I} 35, \mathrm{I} 48$
William, prior of Blyth, N I20

William Putrell of Wymeswold, L 58

William of Pyrhohe (Pirehill, Staffs?) I5

William of Rennes (France) 98, I37-I38

William of Reresby ( $\mathrm{L}$ or Lincs) Leake 8

William of Saint John IO4

William of Sapperton (Lincs) i Io

William Scarlet 67-68, 70

William of Schaterswrt (Chatsworth), D I66

William of Somerville (Norfolk?) 67, 77, 80

William son of Andrew of Hooton, SY IO9

William son of Dolphin I 45

William son of Godric 206

William son of Hugh of Wentworth, SY 9397, 105

William son of Matyne 56

William son of Ranulf $3-4,63$

William son of Robert 3-4, 63, 92

William son of Robert of Alfreton, D 203, 208

William son of Robert of Ogston, D I7

William son of Robert of Wentworth, SY 98, 103

William son of Robert son of Ranulph 6

William son of T. of Lond' 59

William son of Thomas of Sutton, D 209

William son of William of Wentworth, SY IO3

William Spynke of Little Sheffield, $\mathrm{SH}_{152}$ I 53

William of Stainsby, D, lord Intro. 29, 26, 38, 56, 9o, i88, Leake 5, Leake 9

William the tailor 69

William of Tocham (Tockenham, Wilts?) 34

William of Ufton, D 27

William of Ughill, SY I 7

William Underway of Wentworth, SY Ioo

William the Vavassur, lord of Denaby, SY IIO

William of Vernon (France) I76, I9 I

William of Welbeck, N, Brother 3

William of Wentworth, SY Io I, Io6

William of Westhall ${ }_{5} 5,64,76$

William of Wingfield, D 22, I83-I84, I87

William the Waleys 69

William the Wyte 79-8o, 87 


\section{INDEX OF PLACES}

These places do not include those used in personal names; modern place-names are given where possible.

Abbey Brook, D 4, $3^{8}$

Abbey Lane, SH Intro. 25

Abbeydale, SH Intro. 25

Aldefelde (fd. in Norton), D 4, 38

Aldwark, SY IIO $n .2$

Alfreton, D Intro. 2, Intro. 4-7, Intro. $10-I 2$, Intro. $I 7-I 8$, Intro. 20 , Intro. 23 , Intro. 28 , Intro. 3In, 3-4, I7, 22, 24, 26-27, $3^{2-}-33,35$ n. 2, 36-38, 40, 44, 46-47, 6I, $65-67,69-81,83-85,87,89-9$ I, Royal Conf. 6

Alwaldsetes, D I83-I84, I87-I88, Leake 8-9

Annesley, N Intro. $8 n$

Apperknowle, D Intro. 23

Arnedwodedole (fd. in Stanley), N 226

Ashbourne, D Intro. 9

Ashover, D Intro. 6, Intro. 9, Intro. II, Intro. I5, I79-I84, I86-I9o

Ashover Moor, D I83-I84, I87-I88, Leake 7-9

Aston (see Coal Aston, D)

Attercliffe, Intro. 9, $\mathrm{SH}$ I I2-I I3

Auvers (France) I2On

Bakewell, D I66, I9 I

Barlborough, D I8 n. 2, I62 n. I

Barlow, D Intro. 9

Barsfelde (fd. in Alfreton), D 26, 38, 90

Beauchief, D Intro. passim, 3-4, 27, 38, 69, 7I, III, II9, I92

Beeley, D Intro. I5, Intro. I9, I68-I75, Leake 6, Royal Conf. $49^{-} 5^{\circ}$

Beighton, D Intro. 5- 6, Intro. ${ }^{6} 6,{ }_{2} 4$ n. 3, Royal Conf. 34

Bentt, the (fd. in Alfreton), D 74

Biggin Farm, D Intro. 16,222

Bilby, N Intro. 5

Billingley, SY Intro. 5, Intro. 9, Io9

Birchitt, D Intro. 4, 6, 36 n. 2, 38, 50 n. 2

Birchwood, Lower (fd. in Alfreton), D 22, 27, 38, 67-68, 89

Birkinschache (fd. in Stanley), N, 225-226

Birley, D Intro. 6, Intro. $16,24 n$. 3, Royal Conf. 34

Blackwell, D Intro. $5^{n}$

Blankney (Lincs) Intro. IO
Blyth, N Intro. 5, I08 n. 2

Bolsover, D 205, 2 I I

Bolton-on-Dearne, SY Iog n. 2

Botheclyfesyke, the, $\mathrm{SH}_{\mathrm{I}} 5^{\mathrm{O}}$

Boythorpe, D 219 n. I

Bradfield, SY I44 n. I, I49 n. 2

Bradway, D Intro. ${ }_{3}$, Intro. 16 , Intro. 18 , Intro. 25, 6, 2I-22, 29, 35, $3^{8}$

Bramcote, N Intro. $5^{n}$

Brampton, D Intro. 9, Intro. 24, 46 n. 2, 196 n. I, I98 n. I, 217-220, Leake 5

Brincliffe, SH I26-I29, I39-I4I, I5I

Brodenge, SH, Royal Conf. 42

Brockford (fd. in Norton), D $4,3^{8}$

Brockholeclive, SH I35, I47

Brockhurst (fd. in Norton), D 6, 38

Broom, SY, $24 n$. 3, Royal Conf. 46

Burbage Brook, D I6I

Calldwell (fd. in Glapwell), D 2 I0

Calver, D Intro. $5 n$

Campsey Ash (Suffolk) I2-I3, I5-I6, 64, 76

Caushouse Farm (fd. in Brampton, D) Leake 5 n. I

Chancet Wood, D 3

Chaurces (France) Intro. 7

Chesterfield, D Intro. 6-IO, Intro. 2I, Intro. 24, 38 n. 2, I60, I66, I92-I96, I98-202, 217 n. I, 219 n. I, 226

Claiwang (fd. in Glapwell), D 207

Cliffe, the (fd. in Norton), D $30,3^{8}$

Clowne, $\mathrm{D}_{I} 62 n$. I

Coal Aston, D Intro. 19, Intro. 23, 7, 38, 42, $45,9 \mathrm{I}$

Cockshutt (fd. in Norton), D 2I, 23-24, $3^{8}$

Collesalfacra (fd. in Chesterfield), D I96

Comberdale (Kumbardall) (fd. in Wymeswold), L $3^{8}$

Conslopdole (fd. in Stanley), N 226

Cotespark Farm, D 77

Coumbeclyffe (fd. in Norton), D 34

Cousewellende (fd. in Wymeswold), L 4

Cowley, Intro. 23, $\operatorname{Iog} n .4$

Crokesbero (fd. in Alfreton), D 75

Dale abbey, D Intro. 2

Darley, D i66, I72, I88, Leake 8-9 
Darley abbey, D Intro. 2, Intro. I3, Intro. 3o, 213-2I4

Denaby, SY IIO $n .2$

Derby I66, Intro. 2

Der(e)bistret (fd. in Glapwell), D 207, 2 IO

Dewyfyswode/Devellswode/Willswodd (fd. in Ashover), D ı88, Leake 8-9

Doncaster, Intro. 2

Dore, D Intro. 4-6, Intro. 13 , Intro. ${ }^{8} 8-19$, I6I n. 7, 218 n.I

Doreheg, D 3

Doreheseles, D 3-4, 43

Dronfield, D Intro. 4, Intro. $5 n$, Intro. 9, Intro. 12-13, Intro. 15, Intro. 19-20, Intro. $23-24,18$ n. 2, II5, 218 n. I

Dronfield Woodhouse, D Intro. 13

Dunsill, N 203, 205, 2IO-2I I

Dunstorthes Intro. 29, I4I $\mathrm{n} .2$

Eastwood Hall (fd. in Ashover), D I83-I84, I87-I88, Leake 8-9

Ecclesall, SH Intro. $4 n$, Intro. 9, Intro. ${ }^{8}-$ 19, Intro. 23, Intro. 25, II I-I I2, II 9, I33, I53-I54, I58

Ecclesfield, SY IOo n. I, IO9 n. 4, I49 n. 2

Eckington Intro. 19-2I, Intro. 24

Edensor, D i66

Eddlestow (fd. in Ashover), D I83-I84, I87

Edwalton, N Intro. 2, Intro. 5, Intro. $I I-I 2$, Intro. 20, Intro. 23-24, 3-4, 38, 66

Egmanton, N Intro. 5

Eycliff (fd. in Norton), D 25

Fallinge (fd. in Beeley), D I69-170, I76-I78 Falwang (fd. in Palterton), D 204, 207

Five Acres (fd. in Ault Hucknall), D 206, 2 IO

Forest of the Peak (see Peak (Forest), D)

Frankbridge (fd. in Stanley), D 222, 225-226

Frankbridgedole (fd. in Stanley), D 225, 227

Fulsyke (fd. in Norton), D 49

Fulwood, SH Intro. 6, Intro. 9, Intro. ${ }^{4} 4^{-I} 5$, Intro. 18 , Intro. 23 , I6I, Royal Conf. 37 , Royal Conf. $4 \mathrm{I}$

Galeghtres (fd. in Darley), D I72

Glapwell, D Intro. 6, Intro. ${ }_{13}$, Intro. $30,{ }_{16}$ n. $I, 182$ n. I, 203-216

Goldthorpe, SY Intro. 5, Intro. 9, Io6-Io8, IIO

Gosedyrtker, SH i36

Greaves, the (fd. in Beeley), D I74-I75

Greenhill, D Intro. 4, Intro. 20, Intro. 24-25, $3^{-4}, 6$, I8, 33, 38-4I, 43, 55
Greenhill Moor, D 33, 38, 4I

Grenoside, SY 135 n. 2

Hackenthorpe, SY Intro. $I 6$

Hagnaby (Lincs) $4 n .3$

Halches (Upper Haugh, Rawmarsh, SY), I37-I 38

Hallamshire, SH Intro. 6, Intro. 8-Io, Intro. I5, I8 n. 2, I53-154, I6I, Royal Conf. $4 \mathrm{I}$

Halleker, SH Royal Conf. 42

Handley, D Intro. 8, Royal Conf. 3o, Royal Conf. 32

Handsworth, SY Intro. 16 , Intro. 2I, IOI $n$. I, I08 n. 3, I33 n. I

Harewood Grange, D Intro. 6, Intro. 9, Intro. 15 , Intro. 23, I64-167, I72, I83, I87-I88, Leake 5-6, Leake 9

Harewoodhead Dereleyam (fd. in Darley), D I64

Harland Edge (fd. in Beeley), D I64

Harlandford (fd. in Beeley), D I72

Harthill, SY Intro. 7

Hasland, D 219 n. I

Hassop, D Intro. $5^{n}$

Hathersage, D Intro. 9, Intro. I4, Intro. I9, I6I-I62

Hazelhurst (fd. in Coal Aston), D Intro. I9, $42,9 \mathrm{I}$

Heath, D 219 n. I

Hereward's Street (fd. in Ashover), D I83I84, I87-I88, Leake 8-9

Herewise (fd. in Alfreton), D 74

Herringthorpe, D Royal Conf. 46

High Melton, SY I2O n. I

Hipper river, D ı89-190, I99

Hirninghuldoles (fd. in Stanley), N 225-226

Holineforde (fd. in Walton), D I89-19o

Holleford, $\mathrm{SH}{ }_{5} 6$

Hollins, the (Holt House, SH) I52-I54

Holmesfield, D Intro. Io

Hope, D I66

Horepittes, SH I35

Houghton, Stony, D 204, 206, 210-21 I

Hungerhill (fd. in Wymeswold), L 4,38

Hurkelwell (see Ulkelwell)

Hutcliffe Wood, D Intro. 4, Intro. ${ }_{1} 6$, Intro. I8-19, Intro. 25

Hyggehou (Higger Tor) (fd. in Hathersage) D I6I

Inkersall, D Royal Conf. 33

Killamarsh, D Intro. ${ }^{6} 6$

Kilnhurst, SY IOI n. I, I06 n. 4, I33 n. I 
Kimberworth, SY Intro. 5, 93 n. I, 99

Kumbardall (fd. in Wymeswold) L (see also Comberdale) 4

Lady's Cross, (fd. in Hathersage), D Intro. I4, I6I

Lady's Spring Wood, D Intro. $I 8$

Langar, N Intro. $8 n$

Langwith, D $26 n .4$

Leicester, 6 I

Lenton priory, N Intro. 9

Lightokford (fd. in Hathersage), D I6I

Lincoln Intro. 9

Littlemarsh (in vill of Nottingham), N 22I

Litestwood (fd. in Walton), D I89-19o

Little Norton (see Norton, Little, D)

Little Sheffield Intro. I9

Longbenelondichend (fd. in Wymeswold), L 4,38

Longeroda (fd. in Glapwell), D 2 IO

Losk Corner (fd. in Stony Houghton), D 204

Louth Park abbey (Lincs), Intro. 9

Lower Birchwood (see Birchwood, Lower)

Markham, N Intro. $5^{n}$

Marnham, N Intro. 5, Intro. 7, Intro. 3In, $3 \mathrm{I}, 38,44,6 \mathrm{I}$

Marthegravegate (fd. in Wymeswold), L 4 , $3^{8}$

Martynhaw (fd. in Wymeswold), L 4, $3^{8}$

Marwaterlandes (fd. in Wymeswold), L 4,38

Matlock Bridge, D I83-184, I87

Mattersey, N Intro. 9, I20-I25

Meersbrook, D Intro. 4, 4, $3^{8}$

Mikylwaterlandes (fd. in Wymeswold), L 4 , 38

Millhouses, SH Intro. I8-I9, III n. 2, I52 n. I

Milnhill (fd. in Wymeswold), L 4, $3^{8}$

Monk Bretton priory, SY I8 n. 2

Monyash, D Intro. $5 n$

Morelestorth hill (fd. in Glapwell), D 206

Morton, D Intro. IO

Moss Beck (fd. in Eckington) Intro. I9

Mousewelehende (fd. in Wymeswold), L 38

Mylneclyff, SH I57

Nether Padley (see Padley, Nether, D)

Netherbromebergh (fd. in Wymeswold), L 4,38

New Mill, SH Intro. 19,156

Newbold, D Intro. 24, I98, 219 n. I

Newhouse abbey (Lincs), Intro. 3, $18 \mathrm{n.} 2$
Norton, D Intro. 2-7, Intro. ${ }^{10-13}$, Intro. I720, Intro. 28, Intro. 3In, Intro. 32, 3, 4, IO, I7-22, 30, 33, 35-40, 43 n. I, 44-45, 47-48, 50-5I, 53-54, 56, 6I, 66, 8I, 86, 90-9I, Io6 n. 4, I52 n. 2, Royal Conf. I2

Norton Green Intro. 12

Norton Hammer, D Intro. 4

Norton Lees, D Intro. 4, Intro. I2, Intro. 24 , Intro. 29

Norton, Little, D Intro. 24, 33, 38, 40

Norton Wood, D 34, $3^{8}$

Norton Woodseats, D Intro. 4, Intro. I9, Intro. 24-25, I8, 28, 33, 38, 50, Royal Conf. 24

Nottingham I66, 206-207, 210, 221, 226

Nuthall, N Intro. $5^{n}$

Ollerton, N Intro. $5^{n}$

Ormesland/Ormesmedwe (fd. in Beighton), D Royal Conf. 34

Osberton Hall, N Intro. $5 n, 66$

Padley, Nether, D Intro. 9, Intro. I4, 23 n. 2, I6I, I63

Palterton, D 204

Peak (Forest), D 24 n. 3, I04 n. 3, Io n. 2, I66

Peasunhurst (fd. in Ashover), D I83, I87I88, Leake 8-9

Perlethorpe, N Intro. 5

Pleasley, D Intro. 5, 23 n. 2, I84 n. I, 2 IO

Povey, D Intro. 23

Prémontré abbey Intro. 3-4

Prestacra (fd. in Glapwell), D 209

Priestcliffe, D $\operatorname{to} 6$ n. 2

Qwythenegrenes (fd. in Alfreton), D 74

Qwytekere (fd. in Alfreton), D 26, 38, $9^{\circ}$

Rawmarsh, SY Intro. 6, Intro. 7n, Ioo n. I, Io6 n. $4, \operatorname{Iog}$ n. 4, IIO n. 2, I37-138

Ridding (fd. in Westnall), N 82, 210

Riddings (fd. in Alfreton), D Intro. 12

Rikisike (fd. in Wymeswold), L 4, 38

Rivelin Valley, SH Royal Conf. 4I

Roach House (fd. in Ashover), D I83-I84, I87

Robbewong (fd. in Wymeswold), L 4, 38

Robert Rydding (fd. in Alfreton), D 22, 38

Rockley, SY I8 n. 2

Rotherham, SY Intro. 29, 44 n. 2

Rowsley, D Intro. $5 n$

Rowthorne, D Intro. 5, 204, 206, 2II

Rufford abbey, N 7 n. 3, I67 n. I, I92 n. 2

Rutendecloch (fd. in Walton), D I89-I9o 
St Quentin abbey (France) Intro. 3

St Wandrille abbey Intro. 6

Scarcliffe, D 206, 2 Io

Scarsdale, wapentake of, D Intro. 7, Intro. Io, I8 n. 2, I6o, I95, Leake 8-9

Scholes, SY Intro. 5, Intro. 9, 92-IOI, IO3

Schortbuttes (fd. in Glapwell), D 204

Serleforkes (fd. in Ashover), D I83-I84, I87I88, Leake 8-9

Sheaf river, D/SH Intro. 4, Intro. 6, Intro. 9, Intro. I8-I9, 4, 9-10, I8, 21, 28, 33, 34, 38, 49, 50, I 6, I56, Royal Conf. I2

Sheffield, Intro. 4, Intro. 6, Intro. 9, Intro. $2 I$, III-II9, II3 n. I, II4, II 8 n. I, I28 n. 2, I29 n. I, I30-I36, I39 n. 2, I43 n. I, I47-I50, I5I n. 2, I55 n. I, I56-I57, Royal Conf. 38, Royal Conf. 42

Sheffield, Little (see Little Sheffield)

Shirecliffe, SH Iog $n .4$

Shireoaks, D 9, 38

Shooterslea (fd. in Ashover), D I83, I84, i87-ı88, Leake 8-9

Smaligesikend (fd. in Wymeswold), L 4, $3^{8}$

Smithy Wood, D Intro. 19

Somercotes (fd. in Alfreton), D 74

Somersall Hall, D 225-226

Stainborough, SY I8 $n .2$

Stainsby, D 56 n. I

Stamfordsike (fd. in Ashover), D I83-I84, I87

Stanley, N Intro. 6, Intro. I6, Intro. 23, 222, $224-226$

Staveley, D Intro. 5, Intro. 24, Royal Conf. 33

Stefnestubing (fd. in Glapwell), D 206

Stony Houghton (see Houghton, Stony, D)

Storthes, the (fd. in Alfreton), D go

Strawberry Lee, D Intro. 9, Intro. $I_{4}^{-16}$, Intro. 18 , Intro. $23, \mathrm{I} 59, \mathrm{I} 6 \mathrm{I}, \mathrm{I} 63$

Swanwick, D Intro. I8, 22, 38, 69, 84

Swinton, SY Intro. 5, Intro. 9, I04, I06 n. 4, Io9

Tacheleforde (fd. in Norton), D 6

Taddington, D $\operatorname{Io} 6 n$. 2

Teversal, N Intro. 6, Intro. I6, 203 n. 2, 222224, Royal Conf. 45

Thorpe Hesley, SY Intro. 5, Intro. 9, 99-IO3

Thortley (fd. in Alfreton), D 79

Thurgaton priory, N Intro. $5 n, I 8 n .2$

Tibshelf, D $26 n .4$

Tickhill, Honour of Intro. 5, Intro. 7, $92 n$. I, I04 n. I, I06 n. I, I32 n. I

Tideswell, D $\operatorname{I06} n .2$, I66
Todwick, SY, IIO n. 2

Tokeby (unidentified) 66

Tomelingreve (fd. in Alfreton), D 74

Totley, D Intro. 4, Intro. 14 , Intro. I8, I59 $n$. I, I6I $n .7$

Treeton, SY Intro. $21,24 n .3$

Tres Lauhes, D I72

Troway, D Intro. $6,8,3^{8}$

Tugby, L $66 n .2$

Twentywell Lane, D Intro. 3

Twentywellsick (fd. in Beauchief), D $4,3^{8}$

Ulkelwell/Urkelwelsike, SH I34-I36

Umberley Brook, D I72

Unstone, D Intro. $23,36 \mathrm{n.} 2$

Upper Haugh, SY (see also Halches) Intro. 6

Upstall Field (fd. in Ashover), D I82

Wadshelf, D Intro. 8, I64, Royal Conf. 3I

Wadsley, SY Intro. 9, I42-I46

Wadworth, SY Intro. 7

Walton, D Intro. 6, Intro. ${ }_{15}$, Intro. $24,{ }_{1} 64$ n. 3, I83-I84, I87-I9o, Leake 8-9

Watnall, N Intro. $5 n, 82$

Welbeck abbey, N Intro. 2-3

Westerley (fd. in Norton), D 6, 38

Westwood (fd. in Beighton), D Intro. 16

Wetemore (fd. in Ashover), D I83-I84, I87

Whitwell, D ${ }_{1} 62 n$. I

Wigley, D 2 I 7-220

Willswodd (see Dewyfyswode/Devellswode/ Willswodd)

Wingerworth, $\mathrm{D}_{36} 6$ n. 2, I83-I84, I87

Wiverton, N Intro. $8 n$

Wodewardeston (fd. in Brampton), D I72

Woldhyll (fd. in Wymeswold), L 65

Wombwell, SY Iog $n .4$

Woodborough, N Intro. $5^{n}$

Woodhouse, SY Intro. $I 6$

Woodseats (fd. in Thorpe), SY IoI

Worhuldole (fd. in Stanley), N 226

Worksop priory, N Intro. 5, Intro. 6

Wormhill, D Io6 n. 2

Wringandstones (fd. in Ashover), D I83-I84, I87

Wudemangatha (fd. in Glapwell), D 206, 2 Io

Wymeswold, L Intro. 2, Intro. 4-6, Intro. $I I-I 2$, Intro. $I 7$, Intro. 2O, Intro. 22, Intro. 24 , Intro. $29,3^{-5}$, I2-I6, 38, 44, $57-66,76,90^{-}{ }^{-1}$

Wyntersedecrofte (fd. in Alfreton), D 74

York, 220 
